\title{
In vivo and in vitro effects of chronical exposure to nonylphenol on lipid metabolism
}

\author{
Jie Yu (D, Wenmei Li, Lan Tang, Ya Luo and Jie Xu* (1)
}

\begin{abstract}
Background: The incidence of obesity has soared over the last several decades. There is mounting evidence suggesting that the increased presence of environmental endocrine disruptors (EEDs), including nonylphenol (NP), plays an important role in the incidence of lipid metabolism disorders. The aim of this work was to determine whether chronical exposure to NP could induce obesity and lipid metabolism disorders, both in vivo in Sprague-Dawley rats, and in vitro in 3T3-L1 preadipocytes. Forty rats ( $n=10$ per group) were gavaged with NP in corn oil at dose levels of $0.02 \mu \mathrm{g} / \mathrm{kg} /$ day (low dose, L), $0.2 \mu \mathrm{g} / \mathrm{kg} /$ day (middle dose, M), and $2.00 \mu \mathrm{g} / \mathrm{kg} /$ day (high dose, H) or corn oil alone (vehicle control, C) for 180 days. In vitro study, 3T3-L1 preadipocytes were exposed to NP at concentrations of 0, $40 \mathrm{pM}, 40 \mathrm{nM}$, or $40 \mu \mathrm{M}$ for 12 days.

Results: In vivo, the fat weight $(F=103.605, P<0.001)$ and fat coefficient $(F=169.807, P<0.001)$ of NP-exposed rats were higher than those of control group rats. The serum levels of TC $(F=3.798, P<0.05), \operatorname{LDL}-C(F=4.946, P<0.05)$, and $\mathrm{TG}(F=14.117, P<0.05)$ in the $\mathrm{H}$ group were higher than those in the control group. Protein concentrations of $C E B P a$ $(F=189.104, P<0.001)$, FAS $(F=51.011, P<0.001)$, PPARY $(F=114.306, P<0.001)$, and SREBP1 $(F=30.432, P<0.001)$ in serum in the NP group were higher than those in the control group. The concentration of NP in adipose tissues of rats increased with an increase in NP exposure dose in a dose-response manner ( $F=561.353, P<0.001)$. The numbers of adipocytes in the $\mathrm{M}$ and $\mathrm{H}$ groups decreased, and the volume of a single cell increased with cells' membranes ruptured. With the increase in NP exposure dose, the number of adipocytes per microscope decreased gradually $(F=85.873, P<0.001)$. The expression levels of PPARY $(F=169.936, P<0.001)$ and $F A S(F=295.249, P<0.001)$ proteins in the $\mathrm{H}$ group were higher than those in the control group. CEBPa $(F=101.086, P<0.001)$ mRNA expression was up-regulated in the $\mathrm{M}$ and $\mathrm{H}$ groups; and FAS ( $F=439.600, P<0.001)$, PPARY $(F=10.540, P<0.001)$, and SREBP1 $(F=123.499, P<0.001)$ mRNA expression in NP-exposed groups were significantly higher than those in the control group. In vitro, compared with the control group, the Oil Red Staining of adipocytes in the NP groups was darker, the fat cells were more densely distributed, and some of them fused into large lipid droplets. Expressions of CEBPa $(F=539.103, P<0.001)$, FAS $(F=715.740, P<0.001), \operatorname{PPAR} \gamma(F=114.783, P<0.001)$, and SREBP1 $(F=139.600, P<0.001)$ proteins in 3T3-L1 preadipocytes were higher in group exposed to $40 \mu \mathrm{M} N \mathrm{NP}$ than those in the control group.
\end{abstract}

Conclusions: The results of this in vivo and in vitro experiment were consistent, and both have demonstrated that NP exposure interfered with the expression of proteins and/or mRNAs of lipid metabolism-related regulators (CEBPa, FAS, SREBP1, PPARY), promoted the proliferation and differentiation of adipocytes and intracellular accumulation of lipids, and eventually lead to blood lipid disorders and obesity in rats.

Keywords: Nonylphenol, Lipid metabolism, Obesity, 3T3-L1 preadipocytes 


\section{Highlight}

Chronical NP exposure induced lipid metabolism dysfunction in rats.

NP level in adipose tissue increased with NP exposure dose in a dose-response manner.

NP interfered with the expressions of lipid metabolism-related regulators.

\section{Background}

The increasing of obesity rate is a serious global public health challenge [3]. Obesity is a multifactorial and complicated endocrine disease, the pathogens of which involve the interaction of genes and the environment [13]. Although heredity and nutrition are important factors for the rapid spread of obesity, these factors have not explained the magnitude and speed of obesity changes in recent decades [25]. Environmental chemicals are considered to be an important cause of the increased rate of obesity. Environmental endocrine disruptors (EEDs) are one of the types of "environmental obesity factors" [8, 26]. EEDs can interfere with the synthesis, secretion, and metabolism of natural hormones. Meanwhile, EEDs is lipophilic, which increases the duration in adipose tissue. This will not only increase the incidence of obesity, but also reinforce the retention of other lipophilic pollution chemicals, which in turn will produce more adverse reactions [12]. This may explain why obesity is a potential risk factor for many diseases, including cancers. Current epidemiological or animal experiments found $[1,12,13]$ that some EEDs (such as bisphenol A, tributyltin, and phthalates) interfered with lipid accumulation and fat metabolism and resulted in obesity.

Alkylphenol ethoxylates are a class of nonionic surfactants that are widely used in the manufactures of detergents, plastics, paints, cosmetics, and pesticides [14]. Nonylphenol (NP) is a major degradation product of alkylphenol ethoxylate, a lipophilic estrogen chemical, and adipose tissue is one of its target organs $[6,14,20]$. Animal experiments have shown that feeding NP-contaminated water during pregnancy and lactation in rats caused obesity [2]; NP exposure during development led to adrenal hyperfunction and obesity in rats, and adult male offspring also gained weight and adrenal hyperfunction [6, 7]. The above research suggested that even during short periods of exposure to NP in the utero and growing season, the body could cause obesity in adulthood. In view of the existing data, although the early exposure to NP was reported to be related to the occurrence of obesity, but the mechanism is unclear. Therefore, rats were exposed to NP for long term in this study, and to determine whether long-term exposure to low NP concentrations causes obesity and lipid metabolism disorders. Then, NP was exposed to cell 3T3-L1, which is one of the most commonly used cells to establish models of adipocytes in vitro. After fattening chemicals exposure, the cell morphology changed and intracellular triglycerides accumulated [16, 21, 23]. Effects of NP on mRNA/ protein expressions of lipid metabolism-related genes (CEBP $\alpha$, FAS, PPAR $\gamma$, and SREBP1) in vivo and in vitro were performed.

\section{Materials and methods \\ Animal experiments \\ Animals and treatments}

Forty healthy 4-week-old Sprague-Dawley (SD) rats $(150 \pm 10 \mathrm{~g})$ were provided by the Daping Animal Center of the Third Military Medical University (License No. SCXK- 2012-0005). After acclimated to the laboratory environment for 1 week, the rats were randomly divided into four groups of 10 rats each: the control group (C), low-dose NP group (L), medium-dose NP group (M), and high-dose NP group $(\mathrm{H})$. The rats were exposed to NP by gavage for 26 weeks (180 days). The rats were housed in the animal laboratory of the School of Public Health of Zunyi Medical University, and maintained at $22 \pm 2{ }^{\circ} \mathrm{C}$, $60 \pm 5 \%$ relative humidity, with standard conditions with 12-h light and dark cycle. The rats were free to eat, drink, and fed in separate cages. The diet consisted of $63.02 \%$ carbohydrate, $12.5 \%$ fat, and $24.93 \%$ protein. To avoid the influence of NP from the environment, the cages were made of polypropylene materials, and the drinking water was deionized.

\section{$N P$ solution preparation}

NP (Shandong Xiya Chemical Industry Co. LTD, China, purity $=98 \%$ ) was dissolved in corn oil (Luhua, Shandong, China) to prepare solutions $(4 \mu \mathrm{g} / \mathrm{L}, 40 \mu \mathrm{g} / \mathrm{L}$, and $400 \mu \mathrm{g} / \mathrm{L})$. Gavage was performed at $5 \mathrm{~mL} / \mathrm{kg}$ every day at $8 \mathrm{am}$. The groups were as follows: control group (C group, corn oil), low dose (L group, $0.02 \mu \mathrm{g} / \mathrm{kg} /$ day NP), medium dose ( $\mathrm{M}$ group, $0.2 \mu \mathrm{g} / \mathrm{kg} /$ day $\mathrm{NP}$ ), and high dose group (H group, $2.00 \mu \mathrm{g} / \mathrm{kg} /$ day NP). Animal experiments were approved by the Zunyi Medical University ethics committee and all procedures were in stick accordance with the relevant regulations and requirements of the Zunyi Medical University.

\section{Rat weight monitoring and animal scarification}

The body weight of the rats was monitored every week before gavage, and all operations were completed within $1 \mathrm{~h}$ to ensure the time of gavage. The whole blood was 
collected through the abdominal aorta after an overnight fast. After standing for $2 \mathrm{~h}$, the blood was centrifuged at $3000 \mathrm{rpm}$ for $10 \mathrm{~min}$ and serum was kept in a refrigerator at $-80{ }^{\circ} \mathrm{C}$. The gonad fat pad was washed with saline, dried with filter papers and weighed. A piece of $0.5 \times 0.5 \mathrm{~cm}$ fat was fixed with $10 \%$ formaldehyde, and the remaining was divided into packs and frozen in Eppendorf (EP) tube at $-80{ }^{\circ} \mathrm{C}$ for later use. The gonad fat coefficient was calculated: fat coefficient $=$ fat wet weight $(\mathrm{g})$ /body weight $(\mathrm{g}) \times 100 \%$.

\section{Serum lipid detection}

Total cholesterol (TC), triglycerides (TG), high-density lipoprotein cholesterol (HDL-C), and low-density lipoprotein cholesterol (LDL-C) in serum were detected by automatic biochemical analyzer (OLYMPUS, Olympus Optical Co., Tokyo, Japan).

\section{Serum lipoprotein detection}

Protein levels of serum FAS, CEBP $\alpha$, PPAR $\gamma$, and SREBP1 were measured by enzyme-linked immunosorbent assay (ELISA) kits (Solarbio, Beijing, China) in accordance with the manufacturer's instructions. A series of concentration of the standards were diluted according to the instructions $\rightarrow$ add samples (standards and samples) $\rightarrow$ add horseradish peroxidase $\rightarrow$ incubate at $37{ }^{\circ} \mathrm{C}$ for $60 \mathrm{~min} \rightarrow$ wash $\rightarrow$ add substrate $\mathrm{A}+\mathrm{B} \rightarrow$ incubate at $37^{\circ} \mathrm{C}$ for $15 \mathrm{~min} \rightarrow$ add stop solution $\rightarrow 450 \mathrm{~nm}$ to measure optical density (OD). The samples' concentrations were calculated from the standard curve by according to the OD value of the standards.

\section{Detection of NP concentration in adipose tissue}

NP concentration in adipose tissue was measured by high-performance liquid chromatography (HPLC). (1) Preparation of adipose tissue sample: put $100 \mathrm{mg}$ of fresh adipose tissue in a glass tube, add $4 \mathrm{ml}$ of $\mathrm{N}$-hexane/ether (Vol.N-hexane:Vol. ether $=7: 3$ ), homogenize for 8 to $10 \mathrm{~s}$ at $20,000 \mathrm{r} / \mathrm{min}$, then centrifuge at $4000 \mathrm{r} / \mathrm{min}$ for $10 \mathrm{~min}$, take the supernatant into a clean glass tube, evaporate in a water bath at $50{ }^{\circ} \mathrm{C}, 0.1 \mathrm{ml}$ dissolved solution and then transfer to the sample bottle. (2) Chromatographic conditions: chromatographic column (Inertsil ODS-3, $4.6 \mathrm{~mm} \times 250 \mathrm{~mm}, 5 \mu \mathrm{m}$ ); fluorescence detector (excitation wavelength: $275 \mathrm{~nm}$ : emission wavelength: $312 \mathrm{~nm}$ ); column temperature: $40{ }^{\circ} \mathrm{C}$; mobile phase: Vol. of acetonitrile: $\mathrm{Vol}$. of $0.1 \%$ glacial acetic acid $=85: 15$; loading volume: $10 \mu \mathrm{l}$, elution rate: $1.0 \mathrm{ml} / \mathrm{min}$; samples were kept for $6.0 \mathrm{~min}$. Quantitative analysis: NP concentrations in the samples were calculated by a standard curve which was made by NP standards of different concentrations in acetonitrile. All values of samples and standards were determined by the machine. The obtained peak area was used to make a standard curve to calculate the NP concentration in the samples.

\section{Adipose tissue cell counting}

The tissues were fixed for $24 \mathrm{~h}$ with formaldehyde and dehydrated with a gradient of alcohol $(75 \% \rightarrow 80 \% \rightarrow 90 \% \rightarrow 95 \% \rightarrow 100 \%)$, and then embedded in paraffin and sectioned $(4-6 \mu \mathrm{m})$. Slides were stained with $H \& E$ and observed under a light microscope, and then cell counting was performed under the field of view of a $200 \times$ magnification.

\section{Detection of the expressions of lipid metabolism-related proteins (CEBPa, FAS, PPARY, SREBP1) in adipose tissue}

Western blot (WB) was performed to detect the expression levels of lipid metabolism-related proteins (CEBP $\alpha$, FAS, PPAR $\gamma$, and SREBP1) in adipose tissue. $100 \mathrm{mg}$ of adipose tissue was homogenized and lysed in $1 \mathrm{ml}$ RIPA buffer with $10 \mu \mathrm{l}$ phenylmethanesulfonyl fluoride (PMSF) $(100 \mathrm{mmol} / \mathrm{L})$. The lysate was centrifuged at $12,000 \mathrm{r} /$ $\min$ for $20 \mathrm{~min}$ at $4{ }^{\circ} \mathrm{C}$. The protein concentration was determined by the BCA method. Protein solution was diluted to $5 \mu \mathrm{g} / \mu \mathrm{l}$, mixed with loading buffer at volume rate $1: 4$, and then boiled at $100^{\circ} \mathrm{C}$ for $5 \mathrm{~min}$. The proteins were separated by $10 \%$ SDS-PAGE and then transferred to polyvinylidene difluoride (PVDF) Immobilon membrane (Millipore, France). After blocked with 5\% non-fat milk, the membrane was incubated with primary antibody at $4{ }^{\circ} \mathrm{C}$ overnight. The membrane was washed with TBST for 6 times, $5 \mathrm{~min} /$ time in the next day, and the secondary antibody was incubated at room temperature for $1.5 \mathrm{~h}$. The membrane was washed with TBST for 6 times, $5 \mathrm{~min} /$ time, and then exposed with ECL solution. Pictures were analyzed by the Image-J software $(\mathrm{NIH}$, Bethesda, USA), and the internal reference protein was GAPDH.

\section{Detection of the MRNA expressions of lipid metabolism-related genes (CEBPa, FAS, PPARY, SREBP1)}

A real-time RT-PCR was performed with a c1000 thermal cycler (Bio-Rad, Hercules, California USA) to detect the mRNA expressions of CEBP $\alpha$, FAS, PPAR $\gamma$, and SREBP1. $200 \mathrm{mg}$ of adipose tissue was cut and homogenized with $1 \mathrm{ml}$ TRIzol, kept for $5 \mathrm{~min}$ at room temperature (RT) and $200 \mu \mathrm{l}$ chloroform was added and shaked vigorously for $15 \rightarrow$ stand for $5 \mathrm{~min}$ at $\mathrm{RT} \rightarrow$ centrifuged $\left(4{ }^{\circ} \mathrm{C}, 12,000 \mathrm{r} / \mathrm{min} \times 15 \mathrm{~min}\right) \rightarrow$ mixed $400 \mu \mathrm{l}$ supernatant with $400 \mu$ lisopropanol $\rightarrow$ stand for $5 \mathrm{~min} \rightarrow$ centrifuged $\left(4{ }^{\circ} \mathrm{C}, 12,000 \mathrm{r} / \mathrm{min} \times 15 \mathrm{~min}\right.$ ) for $10 \mathrm{~min}$ and discard supernatant $\rightarrow$ washed with $75 \%$ ethanol once $\rightarrow$ discard supernatant, air dry for $5 \mathrm{~min} \rightarrow$ dissolved in 20-50 $\mu$ l DEPC-treated water. Total RNA concentration 
was measured by Nano Photometer. Reverse transcription was performed in according to the instructions of manufacture. qPCR was performed using SYBR ${ }^{\circledR}$-Green Master Mix. The expression level of the target gene was calculated using the calculation formula: $Q=2^{-} \triangle \triangle \mathrm{Ct}$, the internal parameter $\mathrm{Ct}$ value was among $18-25$. The sequences of the primers used are listed in Table 1.

\section{Cell experiments}

\section{Cell culture and exposure}

3T3-L1 preadipocytes (Shanghai Zhong Qiao Xin Zhou Biotechnology Co., Ltd, Shanghai, China) were cultured in high-glucose DMEM supplemented with $10 \%$ newborn bovine serum (NBS) and 1\% penicillin-streptomycin (PS) at $37{ }^{\circ} \mathrm{C}, 5 \%$ carbon dioxide. When cell's confluence was $80 \%$ to $90 \%, 10 \%$ FBS medium was changed and cells were cultured for $48 \mathrm{~h}$. Then, NP $(0,40 \mathrm{pM}, 40 \mathrm{nM}$, $40 \mu \mathrm{M})$ exposure was started. The medium was changed for each $48 \mathrm{~h}$, and the NP exposure continued until 12 days when there were fat drops in the cells.

\section{Oil Red O Staining}

Stained with Oil Red O solution (Solarbio, Beijing, China) for $15 \mathrm{~min}$ at room temperature $\rightarrow$ washed the cells 3 times with PBS, and stained with hematoxylin for $1 \mathrm{~min}$, rinsed with $\mathrm{ddH}_{2} \mathrm{O}$ multiple times, then lipid droplets were observed and photographed under the light microscope.

\section{Determination the related protein expression of interest}

(1) Extraction of total protein: Discard the supernatant and wash the cells 3 times with pre-chilled PBS, add the fresh lysis buffer with $1 / 100$ volumes of PMSF to cell pellets, mix by pipetting, centrifuge $(12,000 \mathrm{r} / \mathrm{min})$ in a pre-cooled EP tube for $20 \mathrm{~min}$ at $4{ }^{\circ} \mathrm{C}$, transfer the supernatant to a new pre-cooled EP tube. (2) The remaining steps were the same as in the animal experiment.

Table 1 The sequences of the primers

\begin{tabular}{ll}
\hline Gene name & Sequences \\
\hline CEBPa & Forward: CTCTGGGATGGATCGATTGT \\
& Reverse: TTACAACAGGCCAGGTTCC \\
FAS & Forward: CTCTGGAAGTGCATGCTGTAAGA \\
& Reverse: GGTAGATGTCATTTGCGAAAGGT \\
PPARY & Forward: ACTGCCTATGAGCACTTCAC \\
& Reverse:GGGTGAGACAGGAGATGTTGGATG \\
SREBP1 & Forward: GTCTTTCAGTGATTTGATTTTGTGA \\
& Reverse: TGTGGTAAAGGTCCGTTCC \\
B-ACtin & Forward: CACCCGCGAGTACAACCTTC \\
& Reverse: CCCATACCCACCATCACACC \\
\hline
\end{tabular}

\section{Data analysis}

All data were statistically analyzed using with SPSS software, version 20.0 for Windows (SPSS Inc., Chicago, IL, USA). The values of all variables are presented as the mean \pm SD (standard deviation). The one-way analysis of variance was used for comparison between multiple groups. If there were differences within the groups, the pairwise comparison between groups was performed by LSD method. A level of $P<0.05$ was considered statistically significant.

\section{Results}

\section{Animal experiment}

\section{Effect of NP exposure on body weight}

There was no significant increase in body weight of rats in the treatment group when NP was exposed from 1 to 5 weeks, and there was an increase trend in body weight of rats in the NP-treated group from 6 to 20 weeks compared with control group, but there was no statistical significance. During the period from 21 to 25 weeks of NP exposure, there was statistical significance between high-dose group and control group, and there was no difference among low-, medium-, and high-dose groups $\left(F_{21 \mathrm{w}}=3.009, F_{25 \mathrm{w}}=3.129, \quad P<0.05\right)$. During 26 weeks (180 days) of NP exposure, there was a continuous increase of body weight showing as follows: $\mathrm{H}$ group $>\mathrm{M}$ group $>\mathrm{L}$ group $>$ control group $\left(F_{26 \mathrm{w}}=3.569, P_{26 \mathrm{w}}=0.023\right.$, Fig. 1).

\section{Effect of NP exposure on fat weight and fat coefficient}

Both fat weight $(F=103.605, P<0.001)$ and fat coefficient $(F=169.807, P<0.001)$ of NP-exposed rats were higher than those of control group rats (Fig. 2).

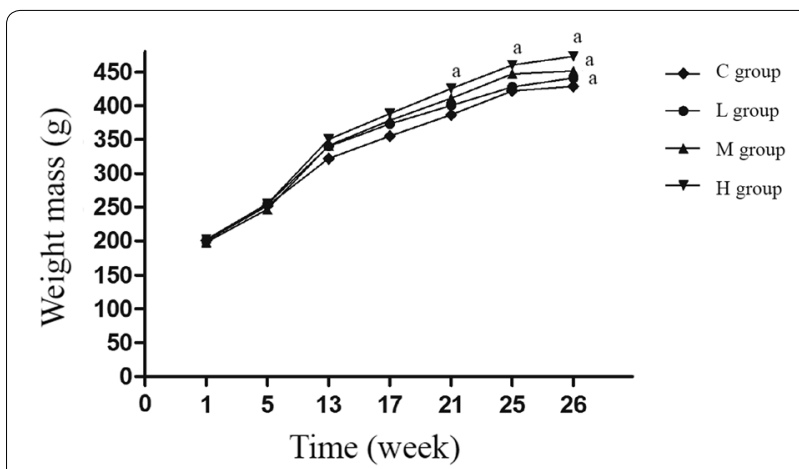

Fig. 1 Effect of NP exposure on rat weight. ${ }^{a}$ vs $C$ group, $P<0.05$ 


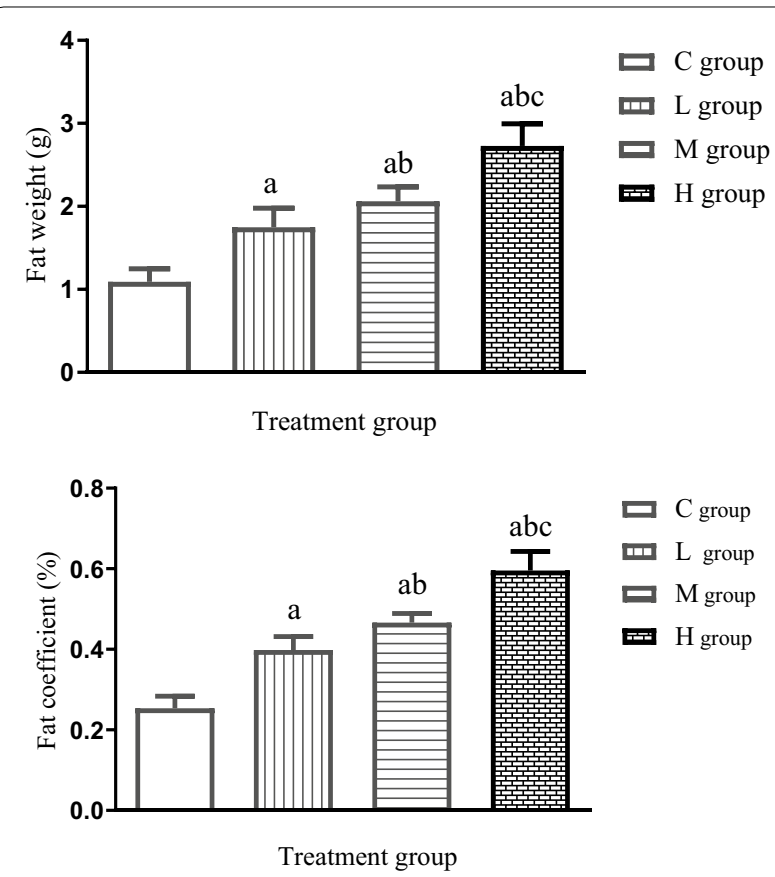

Fig. 2 Effect of NP exposure on fat weight and fat coefficient in rats on 180th days $(n=10) .{ }^{a}$ vs $C$ group, $P<0.05,{ }^{b}$ vs $L$ group, $P<0.05,{ }^{c}$ vs M group, $P<0.05$

\section{Effect of NP exposure on blood lipids}

The serum levels of TC $(F=3.798, P<0.05)$, LDL-C $(F=4.946, P<0.05)$, and TG $(F=14.117, P<0.05)$ in the $\mathrm{H}$ group were higher than those in the control group, but HDL-C concentration did not show statistical difference among the treatment group (Fig. 3).

\section{Effects of NP exposure on serum proteins related to lipid metabolism}

Protein concentrations of CEBP $\quad(F=189.104$, $P<0.001), \quad$ FAS $\quad(\mathrm{F}=51.011, \quad P<0.001), \quad$ PPAR $\gamma$ $(F=114.306, \quad P<0.001)$, and SREBP1 $(F=30.432$, $P<0.001)$ in serum in the NP group were higher than those in the control group. Moreover, the CEBP $\alpha, F A S$, and PPAR $\gamma$ protein contents in the serum indicated the increasing tendency: control group $<\mathrm{L}$ group $<\mathrm{M}$ group $<\mathrm{H}$ group (Fig. 4).

\section{NP concentration in adipose tissues}

The concentration of NP in adipose tissues of NPexposed rats was higher than that of the control group $(F=561.353, P<0.001)$, and concentration trend was indicated as follows: Control group $<\mathrm{L}$ group $<\mathrm{M}$ group $<\mathrm{H}$ group (Fig. 5).

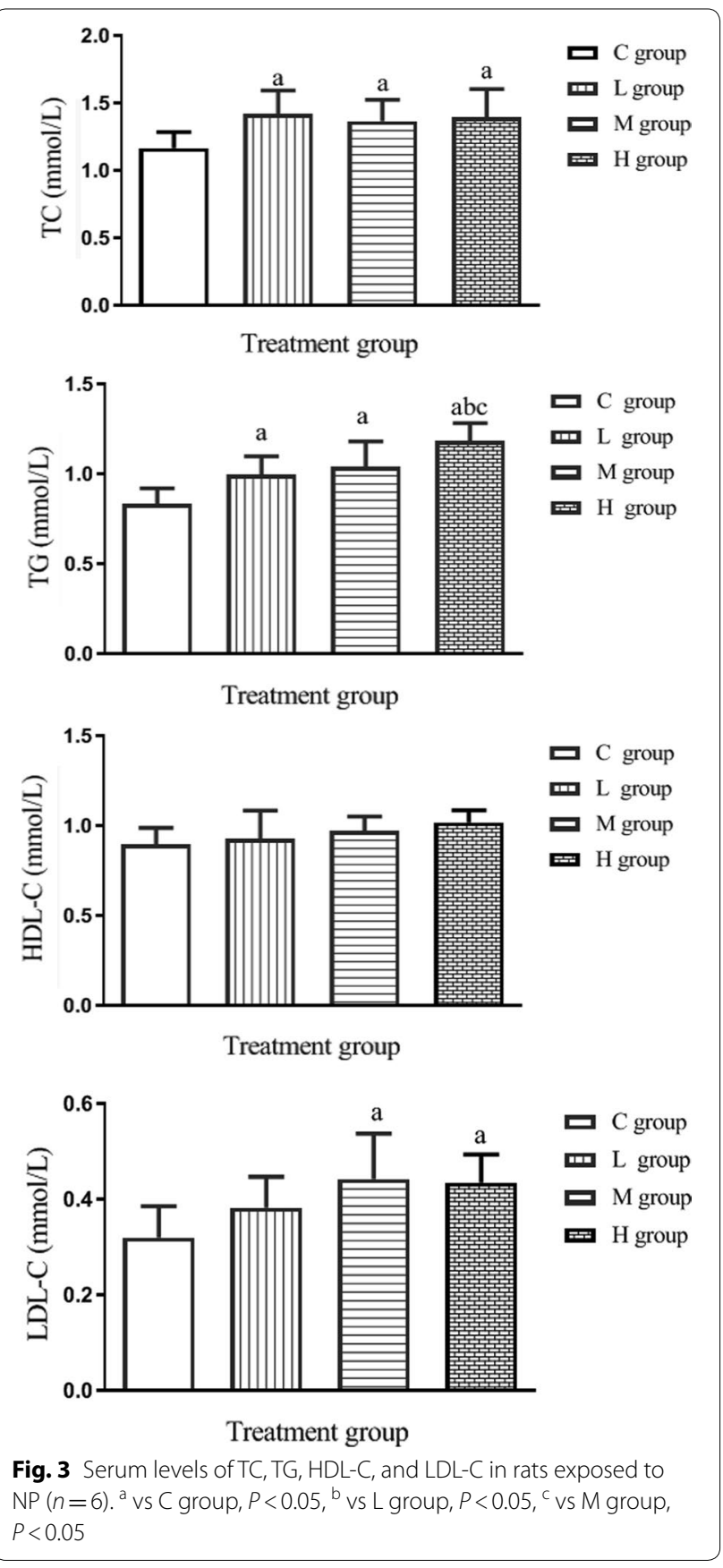

\section{Pathological changes of adipose tissue}

The adipocytes in the control group were small and intact. The adipocytes in the L group became slightly larger. At the same time, some particularly small adipocytes appeared, and it was speculated that they could be newly differentiated adipocytes. The numbers of adipocytes in the $\mathrm{M}$ and $\mathrm{H}$ groups decreased, and the volume of a single cell increased significantly. Moreover, 

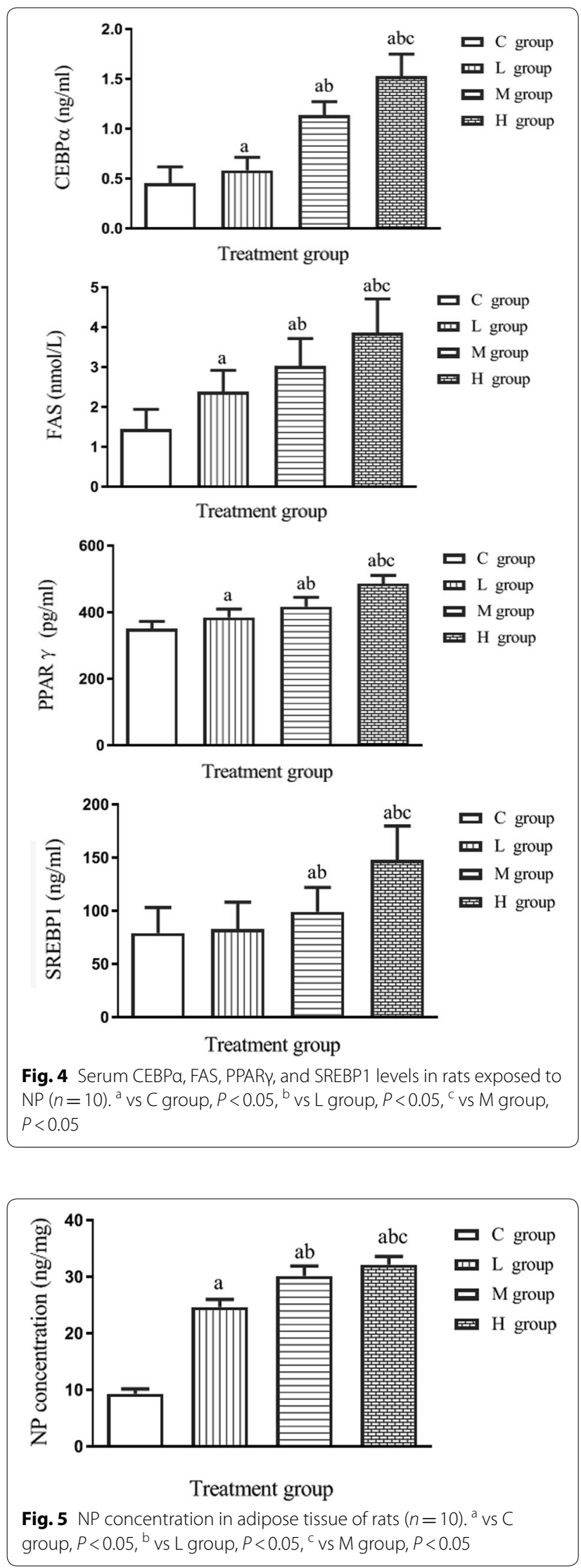

some cells' membranes ruptured when there were large enough, and two or more cells fused (Fig. 6).

\section{Effect of NP on adipose tissue cell numbers}

Cell counting revealed that with the increase in NP exposure dose, the number of adipocytes per microscope decreased gradually $(F=85.873, P<0.001$, Fig. 7$)$.

\section{Effect of NP on the expressions of adipose-related target proteins}

The expression levels of CEBP $\alpha(F=53.403, P<0.001)$ and SREBP1 $(F=213.586, P<0.001)$ proteins in adipose tissue of NP-exposed rats increased with the increase of NP exposure dose; the expression levels of PPARy $(F=169.936, P<0.001)$ and FAS $(F=295.249, P<0.001)$ proteins in the $\mathrm{H}$ group were higher than those in the control group (Fig. 8).

\section{Effect of NP exposure on mRNA expressions of target genes related to lipid metabolism}

mRNA expressions in adipose tissues of the lipid metabolism-related genes were up-regulated in NP-exposed rats. CEBP $\alpha$ mRNA expression was up-regulated in the $M$ and $\mathrm{H}$ groups $(F=101.086, P<0.001)$; and FAS $(F=439.600$, $P<0.001)$, PPARY $(F=10.540, P<0.001)$, and SREBP1 $(F=123.499, P<0.001)$ in NP-exposed groups were significantly higher than those in the control group (Fig. 9).

\section{Cell experiments}

Oil Red O staining of 3T3-L 1 cells exposed to NP

Compared with the control group, the Oil Red Staining of adipocytes in the NP groups was darker, the fat cells were more densely distributed, and some of them fused into large lipid droplets (Fig. 10).

\section{Effect of NP on the expression of lipid metabolism-related proteins (CEBPa, FAS, PPARY, SREBP1)}

Expressions of CEBP $\alpha(F=517.864, P<0.001), \quad$ FAS $(F=124.005, P<0.001)$, PPAR $\gamma(F=286.338, P<0.001)$, and SREBP1 $(F=1640.631, P<0.001)$ proteins in 3T3-L1 preadipocytes were higher in group exposed to $40 \mu \mathrm{M}$ NP than in the control group (Fig. 11).

\section{Discussion}

The increasing incidence of obesity is also a risk factor for many diseases, such as type 2 diabetes, cardiovascular disease, non-alcoholic fatty liver, etc. [18]. Numerous studies have shown that EEDs' exposure was related to the occurrence of obesity [22, 25]. NP is a typical environmental endocrine disruptor. This study aimed to 

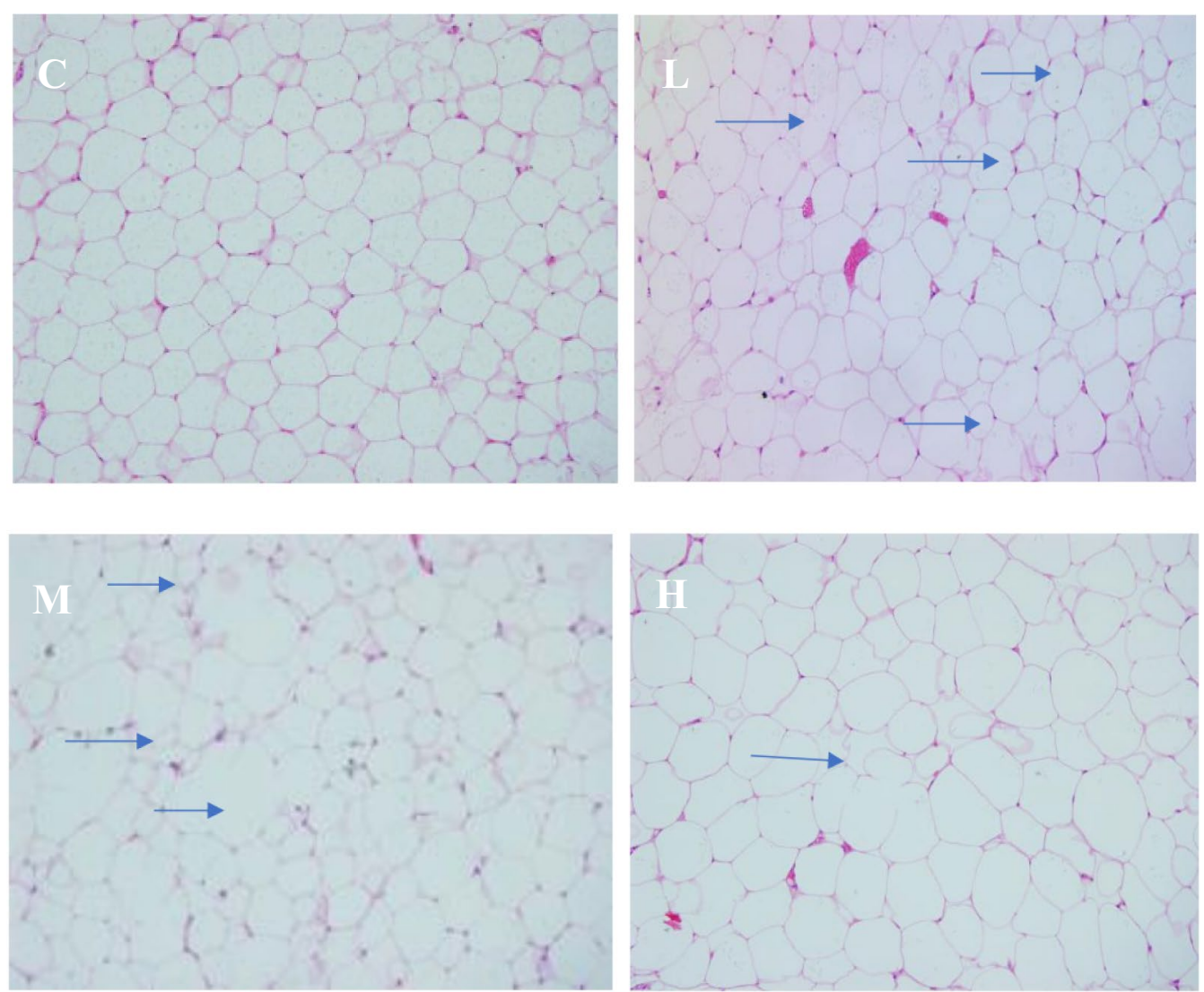

Fig. 6 Pathologic alterations in adipose tissue of rats exposed to NP (200x). Arrows indicate cell hypertrophy, rupture, and fusion

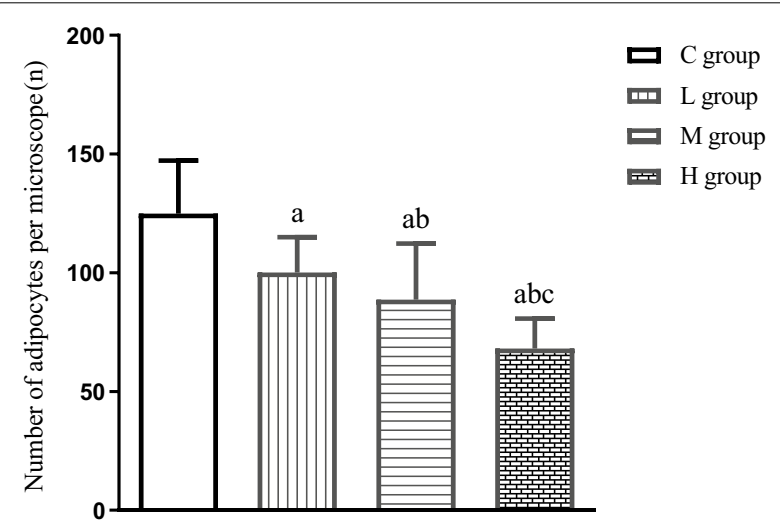

Fig. 7 Effect of NP on adipose tissue cell numbers $(n=50) .{ }^{a}$ vs $C$ group, $P<0.05,{ }^{b}$ vs $L$ group, $P<0.05,{ }^{c}$ vs $M$ group, $P<0.05$

investigate the effect of NP on lipid metabolism through rat models and cell experiments in vitro.

In the current research on the association between NP and obesity, exposure to NP during perinatal period increased body weight, fat weight, serum total cholesterol and glucose levels [24]; NP could be a potential chemical stressor for obesity and obesity-related diseases. However, in some experiments, the exposure duration of NP was short, mostly acute and subacute, and the NP dose was high. Even the "low concentration" in the experiment was much higher than the actual exposure dose in daily life. To better simulate and approximate the NP environmental exposure dose of the general population and the characteristics of long-term exposure in daily life, this study used the around environmental concentration in the NP exposure dose to design a daily NP exposure dose of $0,0.02,0.2$, and $2 \mu \mathrm{g} / \mathrm{kg}$. By simulating the body's NP exposure in the environment for 180 days of long-term intragastric administration of NP to rats, effect of longterm NP environmental concentration exposure on body lipid metabolism was explored.

The results of animal experiments in this study showed that the body weight of rats increased during 1 to 17 weeks of NP exposure, while the weight of rats increased significantly from 21 to 26 weeks and presented a positive relationship with NP dose. NP-induced weight gain in rats has also been demonstrated in multiple 

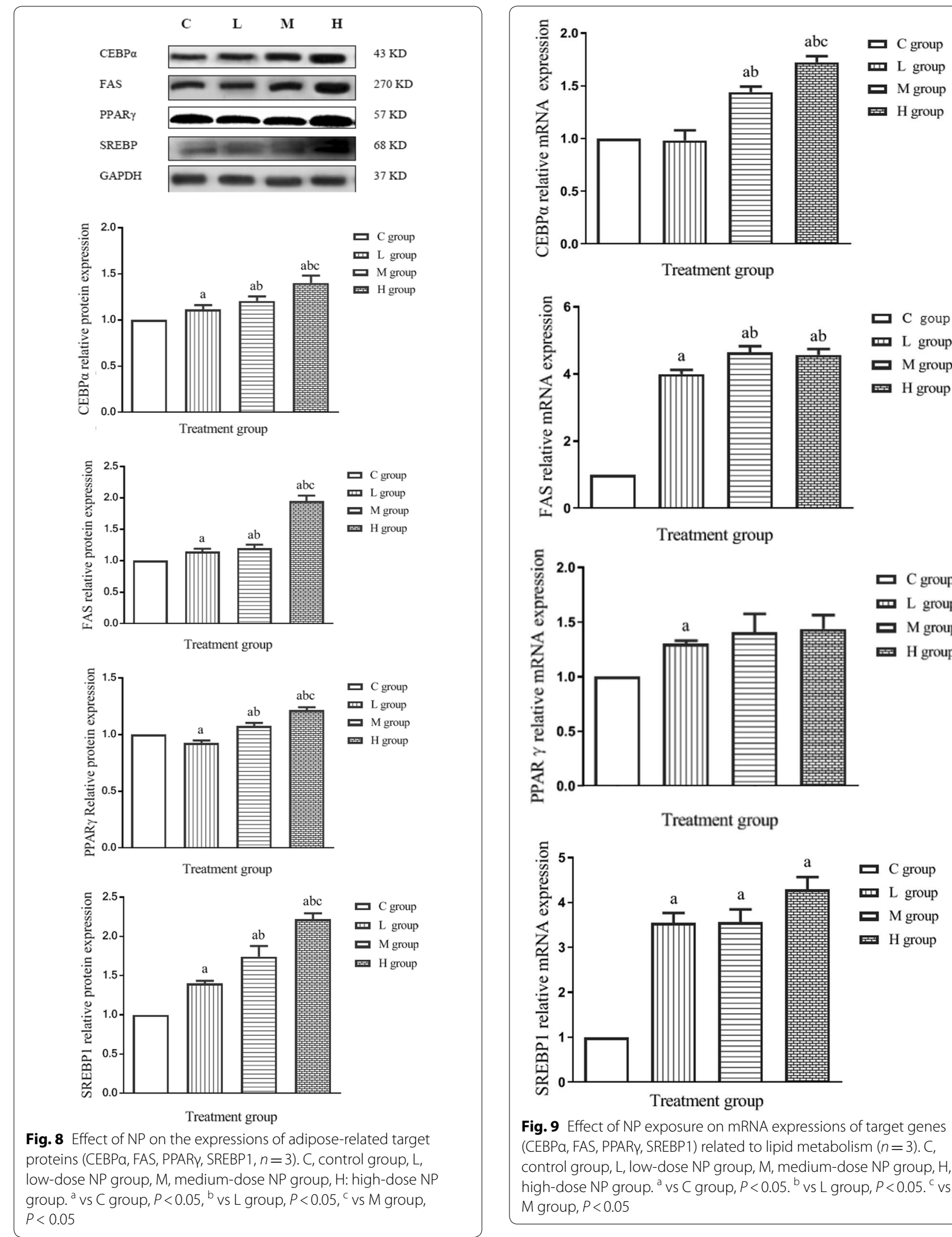

C goup
D L group
M group
m H group

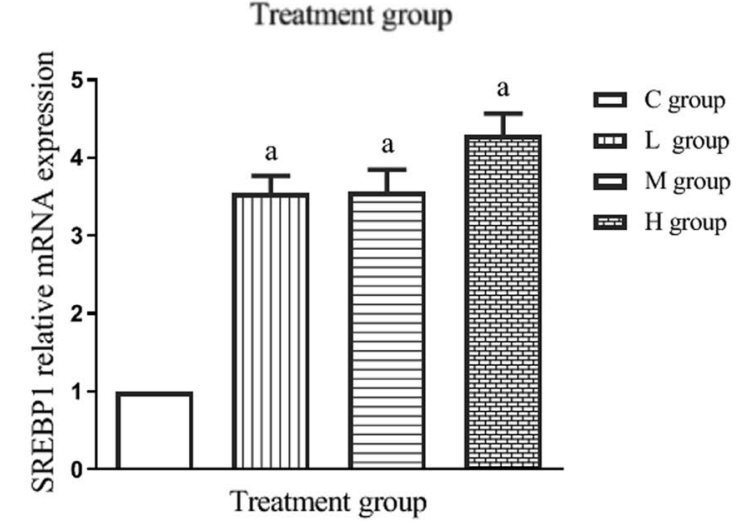

Fig. 9 Effect of NP exposure on mRNA expressions of target genes (CEBPa, FAS, PPARY, SREBP1) related to lipid metabolism $(n=3)$. C, control group, L, low-dose NP group, M, medium-dose NP group, $\mathrm{H}$, high-dose NP group. ${ }^{a} v s C$ group, $P<0.05 .{ }^{b}$ vs $L$ group, $P<0.05 .{ }^{C}$ vs M group, $P<0.05$ 

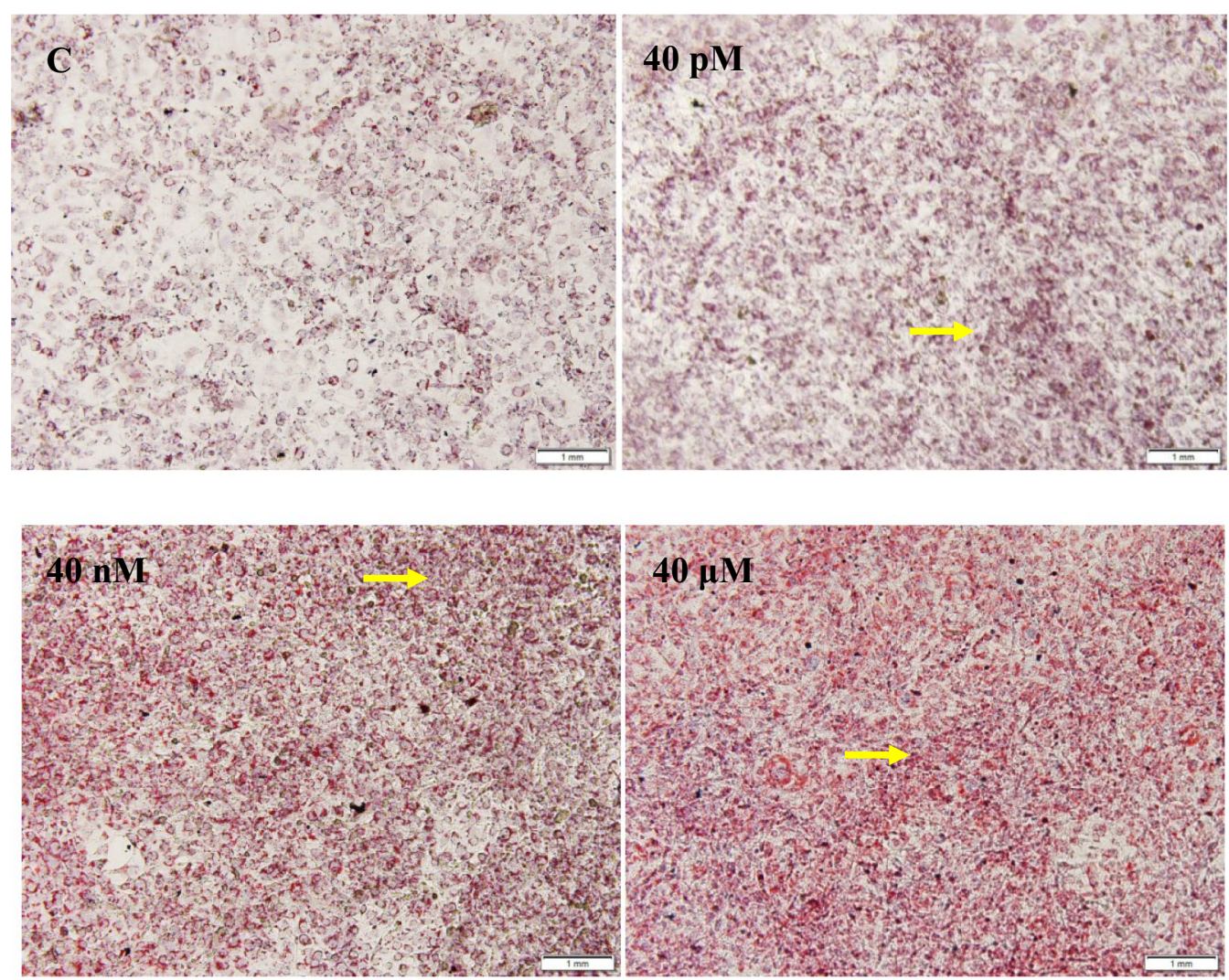

Fig. 10 Oil Red O staining of 3T3-L1 cells exposed to NP (Scale bar, 1 mm). Arrows indicate lipid droplet. C, control group

studies [25, 28, 29]. In this study, the serum cholesterol, triglyceride, and low-density lipoprotein contents of the rats in the exposed group were higher than these in the control group, which was consistent with the results of Zhang et al. [30]. Elevated cholesterol, triglyceride, and low-density lipoprotein levels in serum were also one of the indicators for diagnosing obesity. At 180 days, the gonad fat pad and fat coefficient of the NP exposure group also increased significantly and had a dose-effect relationship. Gonadal visceral adipose tissue is one of the largest adipose depots in rodents [4]. Gonadal fat pad was used as an index of adiposity [9] in the current study. In addition, H\&E staining of adipose tissue revealed that the volume of adipocytes in the exposed group increased with the addition of NP dose and a small volume of newly differentiated adipocytes among them, the large adipocytes with ruptured membrane and multiple cells ruptured shown in high dose group; the accumulation of NP in adipose tissue had a positive relationship with exposure dose. Because the accumulation concentration of NP in adipose tissue had a dose-effect with NP, pathology showed that the higher the exposure concentration, the larger the number of fat cells and the smaller the number.
Therefore, it was assumed a certain association between the exposure dose of NP and the increase in the volume of fat cells. The above results together manifested that long-term exposure to NP could lead to obesity.

CEBP $\alpha$, FAS, SREBP1, and PPAR $\gamma$ are the key genes of lipid metabolism, and involved in the regulation of lipid metabolism. Increased $\mathrm{CEBP} \alpha$ expression was associated with adipocyte hypertrophy, impaired insulin signaling, and decreased glucose utilization [1]; PPAR $\gamma$ and FAS expression and/or reduced phosphorylation-inhibited adipogenesis [15]; SREBP1 participated in adipocyte differentiation and adipogenesis was a major regulator of lipid homeostasis transcription [19]. The results of this animal experiment demonstrated that as the key regulators of lipid metabolism, the protein expression levels of CEBP $\alpha$, FAS, SREBP1, and PPAR $\gamma$ in serum and adipose tissue had a dose-effect with NP exposure. Moreover, the mRNA expression levels of the four regulatory factors were also higher than these of the control group. Some studies had consistent results to this animal experiment, such as the increase of SREBP-1C and FAS mRNA expression in non-alcoholic fatty liver 


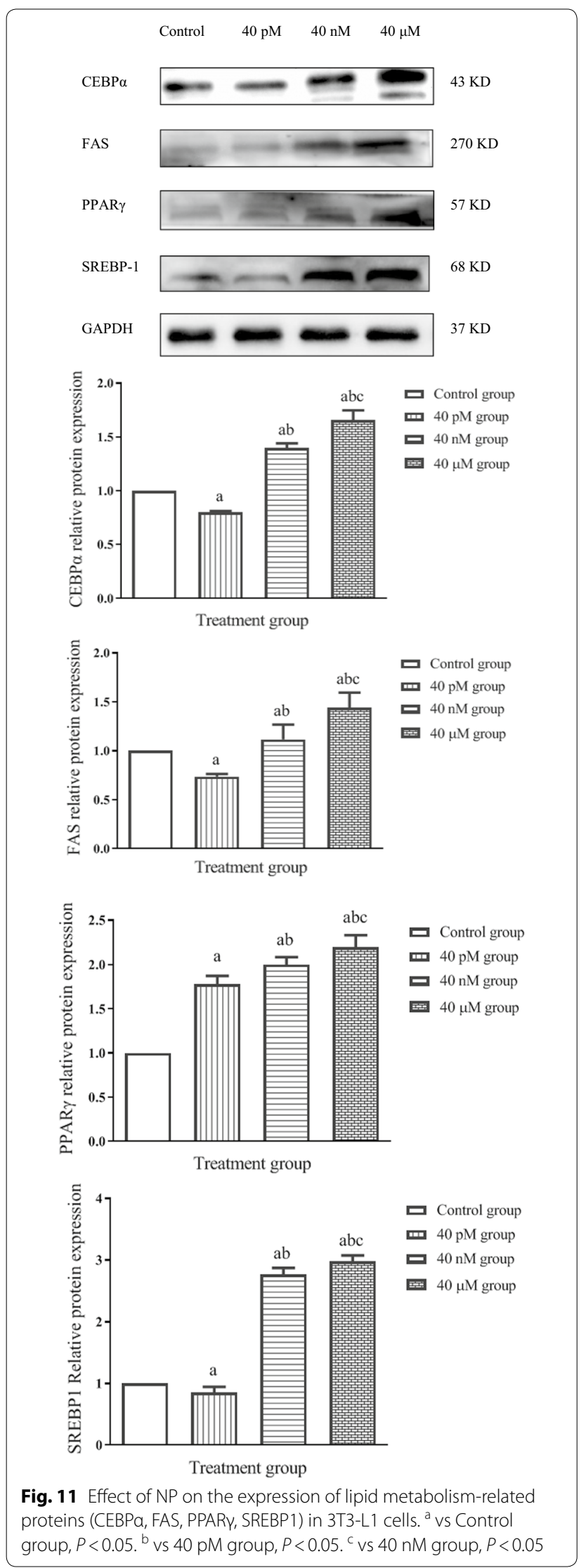

was caused by NP subchronic exposure [29]. Continuous exposure from the 6th day of pregnancy to the 21st day after birth, the expression levels of FAS, PPAR $\gamma$, and SREBP1 mRNA in liver tissues of $F_{1}$ and $\mathrm{F}_{2}$ rats were higher than those in the control group, and the increase was proportional to the dose of NP [30]; NP exposure during the development period could increase PPAR $\gamma$ mRNA expression in adult male offspring [6]. The above lipid metabolism results indicated that NP exposure affected the gene and/or protein expression of CEBP $\alpha$, FAS, SREBP1, and PPAR $\gamma$ in rats related to lipid metabolism.

The results of in vitro and in vivo studies were consistent: more 3T3-L1 cells stained with Oil Red O in the NP exposed group than in the control group. The exposure dose increased, the red color became deeper, and the fat cells were more densely distributed; WB results showed the protein expressions of CEBP $\alpha$, FAS, SREBP1, and PPAR $\gamma$ increased in adipocytes. 3T3-L1 pre-adipocyte in vitro experiments are often used to evaluate the interference of environmental chemicals on adipogenesis, and provide a basis for environmental substances that can affect lipid metabolism in the body $[5,10,24]$. Studies have shown that $[11,17]$ : 4-NP increased PPAR $\gamma$ activity at $1 \mu \mathrm{M}$, and significantly promoted triglyceride accumulation in 3T3-L1 adipocytes at $10 \mu \mathrm{M}$. In addition, Chang et al. [7] found that NP also promoted the protein/mRNA expression of PPAR $\gamma$ in human adipocytes. These studies were consistent with these in vitro results, which suggested that NP exposure had an effect on adipocyte lipid metabolism. The results of the above cell experiments and animal experiments have confirmed our previous research findings that NP exposure could cause 2-diabetes [28], alcoholic fatty liver [29], and metabolic syndrome [27].

\section{Conclusion}

The results of this in vivo and in vitro experiment were consistent, and both have demonstrated that NP exposure interfered with the expression of proteins and/or mRNAs of lipid metabolism-related regulators (CEBP $\alpha$, FAS, SREBP1, PPAR $\gamma$ ), promoted the proliferation and differentiation of adipocytes and intracellular accumulation of lipids, and eventually lead to blood lipid disorders and obesity in rats.

\section{Abbreviations}

EEDs: Environmental endocrine disruptors; NP: Nonylphenol; SD: SpragueDawley; EP: Eppendorf; TC: Total cholesterol; TG: Triglycerides; HDL-C: Highdensity lipoprotein cholesterol; LDL-C: Low-density lipoprotein cholesterol; ELISA: Enzyme-linked immunosorbent assay; HPLC: High-performance liquid chromatography; H\&E: Hematoxylin-eosin; WB: Western blot; PMSF: Phenylmethanesulfonyl fluoride; PVDF: Polyvinylidene difluoride; RT: Room 
temperature; NBS: Newborn bovine serum; PS: Penicillin-streptomycin; SD: Standard deviation.

\section{Acknowledgements}

Not applicable.

\section{Authors' contributions}

$J X$ and JY designed the study. WL, JY, JX, YL and LT analyzed and interpreted the data. WL conducted the laboratory work. JY wrote the manuscript, JX revised the manuscript. All authors read and approved the final manuscript.

\section{Funding}

This work was supported by the National Natural Science Foundation of China (81760580); the Key Program of Scientific and Technological Fund of Department of Science and Technology of Guizhou Province, China (20191466; 2018-1429); the Scientific and Technological Talent Support Program of the Educational Commission of Guizhou Province of China (KY[2018]054); the Excellent Youth Science and Technique Talents of Guizhou Province [2017]5612; 15851 Project Talent in Zunyi municipal government, Guizhou Province (2017, 2018(E-262)). Guizhou High-Level Innovative Talent Support Program ([2020]6014).

\section{Availability of data and materials}

The datasets used and/or analyzed during the current study available from the corresponding author on reasonable request.

\section{Ethics approval and consent to participate}

Animal experimental procedures were approved by Zunyi Medical University Ethics Committee. All methods were performed in accordance with guidelines and regulations of the Zunyi Medical University.

\section{Consent for publication}

Not applicable.

\section{Competing interests}

The authors declare that they have no competing interests.

Received: 13 March 2020 Accepted: 11 June 2020

Published online: 18 June 2020

\section{References}

1. Ariemma F, D'esposito V, Liguoro D (2016) Low-dose bisphenol-A impairs adipogenesis and generates dysfunctional 3T3-L1 adipocytes. PLOS ONE 11(3):e0150762. https://doi.org/10.1371/journal.pone.0150762

2. Biasiotto G, Zanella I, Masserdotti A, Pedrazzani R, Papa M, Caimi L, Di Lorenzo D (2016) Municipal wastewater affects adipose deposition in male mice and increases 3T3-L1 cell differentiation. Toxicol Appl Pharmacol. 297:32-40. https://doi.org/10.1016/j.taap.2016.02.023

3. Bluher M (2019) Obesity: global epidemiology and pathogenesis. Nat Rev Endocrinol 15(5):288-298. https://doi.org/10.1038/s41574-019-0176-8

4. Bodil Bjørndal, Lena Burri, Vidar Staalesen, Jon Skorve, Rolf K Berge (2011) Different adipose depots: their role in the development of metabolic syndrome and mitochondrial response to hypolipidemic agents. J Obes. 2011:490650. https://doi.org/10.1155/2011/490650

5. Borah AK, Singh A, Yasmin R (2019) 1a, 25-dihydroxy vitamin D3 containing fractions of catharanthus roseus leaf aqueous extract inhibit preadipocyte differentiation and induce lipolysis in 3T3-L1 Cells. BMC Complement Altern Med 19(1):338. https://doi.org/10.1186/s12906-019-2754-7

6. Chang LL, Wun WS, Wang PS (2016) Nonylphenol-induced hyperadrenalism can be reversed/alleviated by inhibiting of 11- $\beta$ hydroxysteroid dehydrogenase type 1. Environ Toxicol Pharmacol. 44:1-2. https://doi.org/10.1016/j. etap.2016.03.019

7. Chang LL, Wun WSA, Wang PS (2018) An inhibitor of 11-beta hydroxysteroid dehydrogenase type 1 (PF915275) alleviates nonylphenol-induced hyperadrenalism and adiposity in rat and human cells. BMC Pharmacol Toxicol. https://doi.org/10.1186/s40360-018-0235-0

8. Darbre PD (2017) Endocrine disruptors and obesity. Curr Obesity Rep 6(1):18-27. https://doi.org/10.1007/s13679-017-0240-4

9. Eisen EJ, Roberts RC (1981) Postnatal maternal effects on growth and fat deposition in mice selected for large and small size. J Anim Sci. 53(4):952-965

10. Fan Y, Gan M, Tan Y (2019) Mir-152 regulates 3T3-L1 preadipocyte proliferation and differentiation. Molecules. https://doi.org/10.3390/molecules2 4183379

11. Hao CJ, Cheng XJ, Xia HF (2012) The endocrine disruptor 4-nonylphenol promotes adipocyte differentiation and induces obesity in mice. Cell Physiol Biochem 30(2):382-394. https://doi.org/10.1159/000339032

12. Heindel JJ, Newbold R, Shug TT (2015) Endocrine disruptors and obesity. Nat Rev Endocrinol 11(11):653-661. https://doi.org/10.1038/nrend 0.2015 .163

13. Heindel JJ (2019) History of the obesogen field: looking back to look forward. Front Endocrinol 10:14

14. Huang YF, Wang PW, Huang LW (2014) Nonylphenol in pregnant women and their matching fetuses: placental transfer and potential risks of infants. Environ Res 134:143-148. https://doi.org/10.1016/j.envres.2014.07.004

15. Jang B (2016) Artesunate inhibits adipogeneis in 3T3-L1 preadipocytes by reducing the expression and/or phosphorylation levels of C/EBP-a, PPAR- $\gamma$, FAS, perilipin A, and STAT-3. Biochem Biophys Res Commun 474(1):220-225. https://doi.org/10.1016/j.bbrc.2016.04.109

16. Jiang Y, Ding S, Li F (2019) Effects of (+)-catechin on the differentiation and lipid metabolism of 3T3-L1 adipocytes. J Funct Foods 62:103558. https://doi. org/10.1016/j.jff.2019.103558

17. Kassotis CD, Kollitz EM, Ferguson PL (2018) Nonionic ethoxylated surfactants induce adipogenesis in 3T3-L1 cells. Toxicol Sci 162(1):124-136. https://doi. org/10.1093/toxsci/kfx234

18. Kassotis CD, Stapleton HM (2019) Endocrine-mediated mechanisms of metabolic disruption and new approaches to examine the public health threat. Front Endocrinol 10:39. https://doi.org/10.3389/fendo.2019.00039

19. Lee H, Park Y (2019) Identification of metabolic pathways related to the bisphenol A-induced adipogenesis in differentiated murine adipocytes by using RNA-sequencing. Environ Res 171:161-169. https://doi.org/10.1016/j. envres.2019.01.017

20. Li Wenmei (2019) Study on nonylphenol induced obesity in rats and promoted 3T3-L1 preadipocyte differentiation. Zunyi Medical University, Zunyi; 2019

21. Martiai CN, Gabrielli M, Bonifacino G (2018) Lead enhancement of 3T3-L1 fibroblasts differentiation to adipocytes involves ERK, C/EBP $\beta$ and PPARY activation. Mol Cell Biochem 437:37-44. https://doi.org/10.1007/s1101 0-017-3093-y

22. Mentor A, Brunstom B, Mattsson A (2020) Developmental exposure to a human relevant mixture of endocrine disruptors alters metabolism and adipogenesis in zebrafish (Danio rerio). Chemosphere 238:124584. https:// doi.org/10.1016/j.chemosphere.2019.124584

23. Niu L, Liu Y, Tang G (2019) Placental extract suppresses differentiation of 3T3-L1 preadipocytes to mature adipocytes via accelerated activation of p38 MAPK during the early phase of adipogenesis. Molecules 16:32. https:// doi.org/10.1186/s12986-019-0361-8

24. Park Y, Seo D, Ju J (2019) The antiobesity effects of buginawa in 3T3-L1 preadipocytes and in a mouse model of high-fat diet-induced obesity. BioMed Res Int 2019:1-13. https://doi.org/10.1155/2019/3101987

25. Petrakis D, Vassilopou L, Mamoulakis C (2017) Endocrine disruptors leading to obesity and related diseases. Int J Environ Res Public Health 14(10):E1282. https://doi.org/10.3390/ijerph14101282

26. Ribeiro C, Mendes V, Peleteiro B (2019) Association between the exposure to phthalates and adiposity: a meta-analysis in children and adults. Environ Sci Pollut Res Int 179(Pt A):108780. https://doi.org/10.1016/j.envres.2019.108780

27. Yang J, Yu J, Wang P (2017) The adverse effects of perinatal exposure to nonylphenol on carbohydrate metabolism in male offspring rats. Int J Environ Health Res 27(5):368-376. https://doi.org/10.1080/09603123.2017.1373275

28. Yu J, Yang J, Luo Y (2018) The adverse effects of chronic low-dose exposure to nonylphenol on type 2 diabetes mellitus in high sucrose-high 
fat diet-treated rats. Islets 10(1):1-9. https://doi.org/10.1080/19382 014.2017 .1404211

29. Yu J, Yang $X$, Yang $X$ (2018) Nonylphenol aggravates non-alcoholic fatty liver disease in high sucrose-high fat diet-treated rats. Sci Rep 2018(8):3232. https ://doi.org/10.1038/s41598-018-21725-y

30. Zhang HY, Xue WY, Zhu YS (2018) Perinatal exposure to 4-nonylphenol can affect fatty acid synthesis in the livers of $\mathrm{F} 1$ and $\mathrm{F} 2$ generation rats. Toxicol Res (Camb) 7(2):283-292. https://doi.org/10.1039/C7TX00316A

\section{Publisher's Note}

Springer Nature remains neutral with regard to jurisdictional claims in published maps and institutional affiliations.
Submit your manuscript to a SpringerOpen ${ }^{0}$ journal and benefit from:

- Convenient online submission

- Rigorous peer review

- Open access: articles freely available online

- High visibility within the field

- Retaining the copyright to your article

Submit your next manuscript at $\boldsymbol{\nabla}$ springeropen.com 